\title{
Behavior Modification to Improve Self Confidence of Disabled Student's
}

\author{
Dr. Ravindra M. Ghoti ${ }^{1 *}$
}

\section{ABSTRACT}

The present study has been conducted to investigate the Behavior Modification to improve Self confidence of Disabled Student's in Indian context. Study includes the Disabled School Student's in Aurangabad respectively whom were in the age of 15 to 20 years. To assess the Confidence of the subject the Self Confidence Inventory. Proposed Statistical Procedure is Descriptive statistics i.e. Mean, S.D, will be computed and ' $t$ ' test. Conclusion in this study On the basis of data and discussion of results, the hypotheses were tested and verified. Self confidence of Disabled Student’s can be improved by Behavior Modification.

Keywords: Behavior Modification, Self confidence, Disabled Student's.

One way to help students achieve academic success is to have positive Self confidence. Self confidence to affect a child's ability to learn and to behave in class. Self confidence also seems to affect motivation. Psychology is important as it is concerned with the study of behavior and mental processes and at the same time, it is also applied to many different things in human life. Through psychology, we are able to understand and determine how the mind and body of an individual works. Self-confidence is the inner feeling of certainty; it is a feeling of certainty about who you are and what you have to offer to the world and also it also offers the feeling that you are worthwhile and valuable. Everyone craves to possess self-confidence because it makes life so much easier and so much more fun. Self confidence gives us the energy to create our dreams. Self-confidence is an essential element to being able to create powerfully.

Self-confidence is an attitude which allows individuals to have positive yet realistic views of themselves and their situations. Self-confident people trust their own abilities, have a general sense of control in their lives, and be-live that, within reason, they will be able to do what they wish, plan, and expect. Self confidence is central to good psychological adjustment, personal happiness and effective functioning in children and adults. The term self confidence is used to

\footnotetext{
${ }^{1}$ Department of Psychology, Shivaji Arts, Commerce and Science College, Kannad, Dist. Aurangabad, India *Responding Author

(C) 2016 R Ghoti; licensee IJIP. This is an Open Access Research distributed under the terms of the Creative Commons Attribution License (http://creativecommons.org/licenses/by/2.0), which permits unrestricted use, distribution, and reproduction in any Medium, provided the original work is properly cited.
} 


\section{Behavior Modification to Improve Self Confidence of Disabled Student's}

refer to individual's judgment about themselves. Children with over all high self concepts are confident about their abilities to accomplish their goals, academic competence and relationship with parents and peers. Children with low self confidence tend to be apprehensive about voicing unpopular or un-usual ideas and avoid attracting attention. The future of students depends mostly on their self-confidence. Self-Confidence is the essential factor of personality. On the strength of self-confidence the students can solve the difficulties in individual, social, intellectual, educational fields.

“The socio-psychological concept of self-confidence relates to self-assuredness in one's personal judgment, ability, power, etc., sometimes manifested excessively.”

"Self-confidence is confidence in oneself, i.e. in one's abilities and worth, including the ability to cope with one's limitations and problems.”

In India, the broad definitions of different categories of disabilities have been adopted in the Persons with Disabilities (Equal Opportunities, Protection of Rights and Full Participation) Act, 1995 as well as under the Rehabilitation Council of India Act, 1992.

1.1 "Person with Disability" means a person suffering from not less than forty percent of any disability certified by a medical authority.

1.2 Blindness refers to a condition where a person suffers from any of the following conditions, namely:_ Total absence of sight; or_ Visual acuity not exceeding 6/60 or 20/200 (Snellen) in the better eye even with correction lenses; or _ Limitation of the field of vision subtending an angle of 20 degree or worse. For deciding the blindness, the visual acuity as well as field of vision has been considered.

1.3 "Person with low vision" means a person with impairment of visual functioning even after treatment or standard refractive correction but who uses or is potentially capable of using vision for the planning or execution of a task with appropriates assistive device.

This definition is incomplete as it inadvertently omits quantification of the acuity as well as the field of vision as is done in the case of the WHO definition. It is desirable to modify this definition and the following quantification should be added:

"Low vision are those who suffer visual acuity between 20/ 200 to 70/200 (Snellen) or 6/18 to $6 / 60$ in the better eye after the best possible correction or a Field of Vision between 20 to 30 degree.” Behavior modification is based on methodological behaviorism, which refers to limiting behavior-change procedures to behaviors that are observable and was employed briefly during the late 1950s but predominately from the late 1970s to early 1980s. Specifically, behavior was modified through the use of presumed consequences, including positive and negative reinforcement contingencies to increase desirable behavior or by administering extinction and or punishment to reduce behavior. 
The present study has been conducted to investigate the Behavior Modification to improve Self confidence of Disabled Student's” in this study of Maharashtra, India

\section{Significance of the study}

- This study may provide quantitative data on effect of Behavior Modification to improve Self confidence of Disabled Student's.

- The study may highlight the importance of the Disabled Student's as field of inquiry for profound our understanding of the nature, predication of Self confidence.

- The study may bring an impetus for future experimental studies regarding the effect on prediction of behavior on the bases of Disabled Student's.

\section{METHODOLOGY}

\section{Objectives:}

1. The purpose of this study is to determine whether Behavior Modification to improve Self confidence of Disabled Student's.

2. To explore whether Self confidence affect Disabled Student's.

3. To suggest the importance of individual's Disabled Student's is predictive of their compatibility with others.

\section{Hypotheses:}

- $\quad$ Self confidence of Disabled Student’s can be improve by Behavior Modification.

\section{Sample:}

Locus of the present investigation will be confined to the Disabled Student's initially 1000 subject will be taken from the population finally 100 subjects will select for this study from Aurangabad District Student's School . The stratified randomize sample taken into consideration for the study consisted of 50 subjects'. The efforts will be made to have the sample as representative as possible in terms of area of living.

\section{Measurement Tool:}

\section{Description of the Self- Information Schedule:}

This schedule was saturated by to collect the following facts about the student. Personal Information:- Name, Sex, Age, Caste, Education

\section{Self Confidence Inventory _PD}

Constructed by D.D. Pandey in this test good validity and Test-Retest Validity .8822 and Split half reliability .08924 
Behavior Modification to Improve Self Confidence of Disabled Student's

\section{Design:}

Quasi-experimental design (Time Series Design ) $\mathrm{O}_{1} \quad \begin{array}{lll}\mathrm{X} & \mathrm{O}_{2}\end{array}$

\begin{tabular}{|l|l|l|}
\hline $\mathbf{O}_{1}$ & $\mathbf{X}$ & $\mathbf{O}_{\mathbf{2}}$ \\
\hline Pre-test & After (ten day) Treatment & Post-test \\
\hline $\begin{array}{c}\text { Self Confidence } \\
\text { Inventory_PD }\end{array}$ & Behavior Modification & Self_Confidence \\
& & Inventory_PD \\
\hline
\end{tabular}

\section{Variables under Study}

I) Independent variable

Disabled Student's

\section{II) Dependent variable}

Behavior Modification

Self Confidence

\section{Proposed Statistical Procedure:}

I) Descriptive statistics i.e. Mean, S.D, will be computed.

II) ' $\mathrm{t}$ ' test

\section{RESULT ANALYSIS}

Hypothesis Self confidence of Disabled Student's can be improve by Behavior Modification.

Table 2. Means Disabled Student's for Self confidence

$d f=(N 1+N 2-2) \quad 40+40-2=78$

\begin{tabular}{|l|l|l|}
\hline & N & Mean \\
\hline Pre test & 40 & 26.7 \\
\hline Post Test & 40 & 19.9 \\
\hline
\end{tabular}

$d f=78$ table values is $0.01=2.63 \& 0.05$ level $=1.99$ both level is Significant

Fig .1: Bar diagram showing Mean values for Disabled Student's for Self confidence

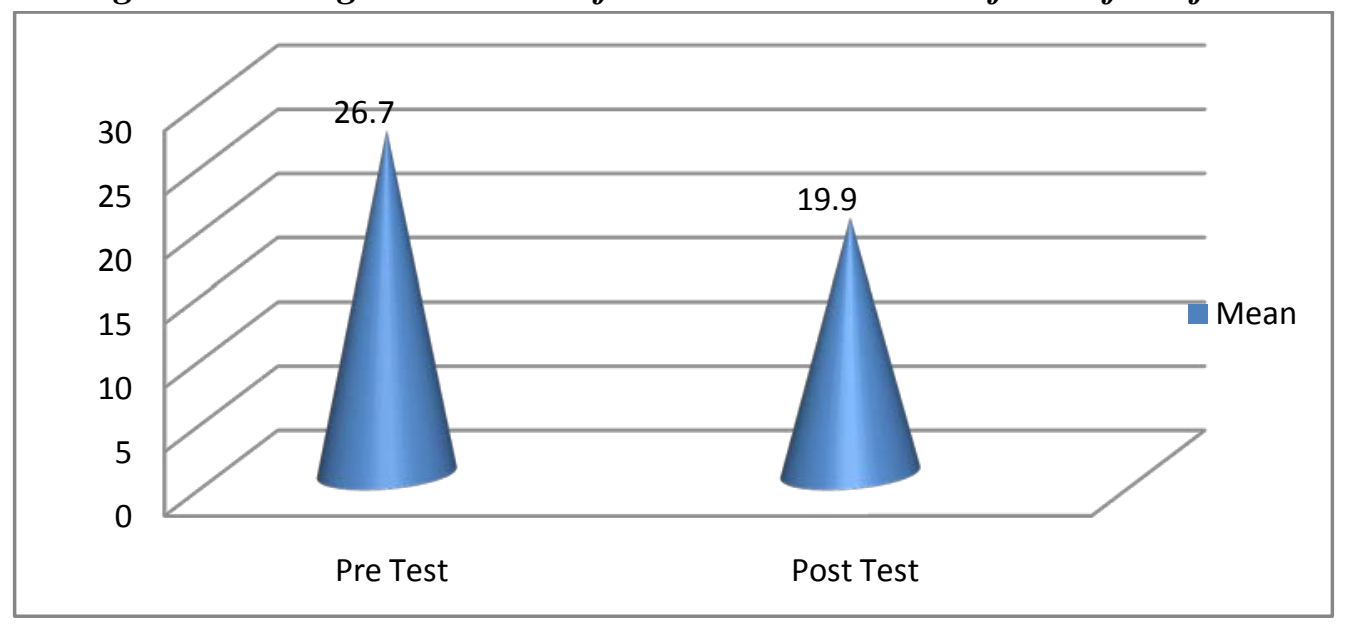

(C) The International Journal of Indian Psychology, ISSN 2348-5396 (e)| ISSN: 2349-3429 (p) | 135 


\section{Behavior Modification to Improve Self Confidence of Disabled Student's}

Table 1 and Figure 1. present the mean on the Self confidence for Disabled Student's. It can be observed from the table that the score of the Disabled Student's Per test mean is Average Self Confidence than Disabled Student's Post test mean is High Self Confidence

Table 3. ' $t$ ' value for Disabled Student's for Self confidence

\begin{tabular}{|l|l|l|l|l|}
\hline & N & Mean & S.D & 't' value \\
\hline Pre test & 40 & 26.7 & 2.27 & 8.83** \\
\cline { 1 - 4 } Post Test & 40 & 19.9 & 1.37 & \\
\cline { 1 - 3 }
\end{tabular}

Table 3. Presents the $t$ value for the Disabled Student's (Per test and Post test) on Self confidence. Significant effect was found for Disabled Student's ( $\mathrm{t}=8.83>0.001$ \& 0.005 Level) on Self confidence.

Thus the result is support to Hypothesis Self confidence of Disabled Student's can be improved by Behavior Modification.

\section{CONCLUSIONS}

On the basis of data and discussion of results, the hypothesis was tested and verified following conclusions were drawn.

- $\quad$ Tend to show Self confidence of Disabled Student's can be improved by Behavior Modification.

\section{LIMITATIONS AND SUGGESTIONS OF THE PRESENT RESEARCH}

Some limitations inherent in this study are;

- The population was limited areas restricted to Aurangabad district only. It can be spread into other areas also.

- The sample of the study was small. The study can also be done by taking large sample size.

- The tools used in this investigation were self - reporting instrument, it is therefore noted that the accuracy of data reported is limited to the abilities and willingness of the respondents to give truthful responses.

- Area of living i.e. environment as well as rural and urban factors and socio-economic status, cultural factors of the subjects were not considered as a determinant of Self confidence It can also be considered as predicators of Self confidence.

\section{Acknowledgments}

The author appreciates all those who participated in the study and helped to facilitate the research process.

\section{Conflict of Interests}

The author declared no conflict of interests. 


\section{REFERENCES}

Agnihotri R (1987). Manual for agnihotri’s self confidence inventory (ASCI) National Psychological Corporation, 4/230 Kacheri Gate, Agra, India.

Agnihotri R (1987). Manual for agnihotri’s self confidence inventory (ASCI) National Psychological Corporation, 4/230 Kacheri Gate, Agra, India.

Bachani, (Dr.) D.; and Limburg, (Dr.) H. (1996): National Programme for Control of Blindness Course Material for Training District Programme Management, New Delhi: Ophthalmic Section, Directorate General of Health Services, Ministry of Health \& Family Welfare, P. 169

Baquer, Ali; and Sharma, Anjali (1997): Disability: Challenge Vs Response, New Delhi: Concerned Action Now, P. 418

Chapman, Elizabeth K.; and Stone, Juliet M. (1988): Visually Handicapped Child in Your Classroom (Special Needs in Ordinary Schools), London: Cassell Educational Ltd., P. 206

Flaming l, Agacer G, Uddin N (2010). Ethical decision-making differences between Philippines and United States Students. Ethics Behav., 20(1): 65-79.

French DJ, West RJ, Elander J, Wilding JM (1993). Decision making style, driving style and self-reported involvement in road traffic accidents. Ergonomics, 36(6): 627-644.

http://www.websters-online-dictionary.org/definition/self-confidence (2010-02-11)

Lopez FL (1977). The making of a manager. Mumbai: Taraporevala.

Ministry of Law, Justice \& Company Affairs (1996): The Persons with Disabilities (Equal Opportunities, Protection of Rights and Full Participation) Act, 1995 (No. 1 of 1996), New Delhi: The Gazette of India, P. 24

Myers IB (1962). Introduction to Type: A description of the theory and applications of the Myers-Briggs type indicator. Consulting Psychologists Press, Palo Alto Ca.

Self-confidence search on Webster's online dictionary on internet:

Self-confidence site on internet: www.self-confidence.com (2010-02-11)

World Health Organization (1980): International Classification of Impairments, Disabilities, and Handicaps, Geneva, P. 205

World Health Organization (1992): Management of Low Vision in Children, P. 7

Yadav SK, Yadav H, Mukherjee S (2009). Comparative study of cognitive worry, somatic tension and self-confidence between west zone Inter-Varsity National level volleyball players. PERSIST, 1(1): 87-92.

How to cite this article: R Ghoti (2016), Behavior Modification to Improve Self Confidence of Disabled Student's, International Journal of Indian Psychology, Volume 3, Issue 4, No. 74, ISSN:2348-5396 (e), ISSN:2349-3429 (p), DIP:18.01.034/20160304, ISBN:978-1-365-46362-4 